\title{
Rumors of Freedom: Torghud Escape from Kirghiz Slavery, 1771-1785
}

\author{
JAYMIN KIM
}

Rice University

In January 1771 over 30,000 Torghud households left the Volga in order to make their new home in Zungharia. When they reached Zungharia by July, however, they had been greatly weakened by Kazakh and Kirghiz raids and forced to submit to Qing rule. Thus the "Flight of the Kalmyks" was transformed into the "Return of the Torghuds." In this paper, I will focus on the Torghuds who escaped Kirghiz slavery to become Qing subjects. In addition to providing a case study, this paper has two larger aims. First, I will highlight the historical value of the Torghud slave narratives from October 1771 to September 1772 that survive in Manchu-language Qing palace memorials. Second, using these slave narratives, I will argue that the Torghud experiences of bondage and freedom highlight the boundaries of subjecthood that existed in Qing Xinjiang and its Central Asian frontier.

\section{傳言中揭示的自由:1771至1785年土爾扈特 人逃離吉爾吉斯奴役過程紀實}

JAYMIN KIM 金載民

萊斯大學亞洲跨國研究系

摘要

清乾隆三十五年十一月 (1770年1月), 三萬余戶土爾扈特人家從伏爾加河畔啓程, 並 於翌年六月抵達準噶爾 (北疆)。然而, 他們在途中履受哈薩克、吉爾吉斯人襲擊, 且被 迫向清王朝投誠。由此, 本應名爲「卡爾梅克遷徙」的一場歷史事件, 變爲了「土爾扈特 歸順」0本篇論文的首要研究對象便是在此時段中從吉爾吉斯奴役下逃離後降清的土 爾扈特人。除了對他們的歷程做出案例分析之外, 本文還旨在提出兩條論點: 其一、乾 隆三十六年(1771年)九月至三十七年九月期間清宮滿文奏摺中對土爾扈特人擺脫 奴隸身分經歷的記載具有着不可小覻的歷史價值; 其二、從土爾扈特人對奴役生涯與 自由生涯體驗的描述中, 可以洞察到清代新疆境內(以及位於中亞地區的新疆邊界)「 統治者」與「受管轄者」之間關係的具體界限位於何處。 
From the "Flight of the Kalmyks" to the "Return of the Torghuds"

On January 5, 1771, 30,909 Torghud households under Ubashi (r. 1762-71) left the east bank of the Volga in order to make their new home in Zungharia. This was a collective decision made by Ubashi and other Torghud leaders after three decades of intensifying Russian colonization and Russo-Torghud conflicts. By 1770, the Torghud pastures had been surrounded by the Russian defensive lines, which severely curtailed their freedom of movement, and the growing Russian demand for military service and other duties put great pressure on Torghud society. The advocates of the exodus, especially the Zunghar refugees driven out of their former home by the Qing army in the 1750s, had claimed that they could reclaim Zungharia and gain free pastures once again. This monumental event is known as the "Flight of the Kalmyks" in Russian historiography. ${ }^{1}$

Contrary to their expectations, the Torghuds were not able to establish an independent regime in Zungharia. First, the journey from the Volga to Zungharia was an arduous one. Torghud passage through the Kazakh domains was especially hazardous, as the Kazakhs launched merciless slave raids against the Torghuds. Throughout the last leg of the journey around the Issyk Kol region, the Torghuds became targets of Kirghiz raids as well. Indeed, by the time the Torghuds reached Zungharia in July 1771, their number had dwindled to about 15,000 households, and they had also lost most of their livestock. ${ }^{2}$ Second, the Torghud destination of Zungharia had been under Qing occupation for over a decade now, forming the northern half of Qing Xinjiang. Benjamin Levey's research shows that the Qing court initially believed that the Zunghar refugees were planning an invasion of Zungharia. Levey is certainly right to argue that this fear shows the fragility of Qing rule in Zungharia. Still, the Torghuds chose to submit to Ili military governor Šuhede in July. Even though the formal submission to the Qianlong emperor happened three months later in the imperial summer palace at Chengde, the Torghuds were promised pastures in Zungharia, which essentially turned them into Qing subjects. ${ }^{3}$ As Peter Perdue has shown, Qing imperial historiography dubbed this event the "Return of the Torghuds," which retroactively made the Torghuds into Qing subjects who had left Qing rule over a century earlier and then returned. ${ }^{4}$

In this paper, I will focus on the Torghuds who escaped Kirghiz slavery to become Qing subjects. To my knowledge, there is no scholarly analysis of the topic, although Levey offered a short analysis of the Torghuds escaping Kazakh slavery in his 2013

1. Michael Khodarkovsky, Where Two Worlds Met: The Russian State and the Kalmyk Nomads, 1600-1771 (Ithaca: Cornell University Press, 1992), 220-35.

2. Christopher P. Atwood, Encyclopedia of Mongolia and the Mongol Empire (New York: Facts On File, 2004), 180.

3. Benjamin Samuel Levey, "Jungar Refugees and the Making of Empire on Qing China's Kazakh Frontier, 1759-1773" (Ph. D. dissertation, Harvard University, 2013), 210-55.

4. Peter C. Perdue, China Marches West: The Qing Conquest of Central Eurasia (Cambridge, MA: Belknap Press of Harvard University Press, 2005), 292-9. 
dissertation..$^{5}$ In addition to providing a case study on this unexplored topic, this paper has two larger aims. First, I will highlight the historical value of the Torghud slave narratives from October 1771 to September 1772 that survive in Manchu-language Qing palace memorials. Second, using these slave narratives, I will argue that the Torghud experiences of bondage and freedom highlight the boundaries of subjecthood that existed in Qing Xinjiang and its Central Asian frontier. As we will see below, the news of Torghud incorporation as Qing subjects journeyed across the Qing's Central Asian frontier, prompting the enslaved Torghuds to escape their masters or their masters to hand them over to the Qing state.

Torghuds, Kirghiz, and the Meaning of Qing Subjecthood

Before we analyze these narratives in detail, we first have to dwell on the meaning of Qing subjecthood. In the Manchu-language palace memorials that I have analyzed, Qing officials use the term albatu to refer to this concept. Onuma Takahiro's meticulous research on documents presented by the Kazakhs, the Kirghiz, Kokand, Badakhshan, and Bolor to the Qing state in the mid-eighteenth century is informative here. By comparing the Chinese, Manchu, Turkic, and Persian documents, Onuma has concluded that the Mongol-style ejen-albatu relationship was the conceptual axis of Qing rule over Central Asia. With its emphasis on a nomadic master-servant relationship, where the albatu bore various duties imposed by the ejen, this relationship was fundamentally different from the Chinese-Confucian relationship between the emperor and his dependency (Ch. fanshu 藩屬). In that sense, Onuma's "ejen-albatu relationship" hypothesis provides yet another example of the Inner Asian roots of Qing imperial formation. ${ }^{6}$

Here I would like to use the Torghud slave narratives to highlight the protection that the Torghuds were afforded as the new albatu of the Qianlong emperor. To illustrate this point, let us first look at Sayaq Kirghiz Ioitubes' visit to Uchturfan on September 29, 1771. Ioitubes had a message from his father Mingilha, the biy (Ma. bii) of the Sayaq Kirghiz pasturing in the At-Bashy River area, for Uchturfan amban Iletu and Tusangga. According to Mingilha, the Kirghiz living in a place called Koman Tubet, which was near Andijan, had raided the Torghuds. Mingilha's Sayaq Kirghiz were also on their way to raid the Torghuds when they learned that the Torghuds had submitted to the Qianlong emperor and been sent to Ili. They accordingly turned back without raiding the Torghuds. Iletu and Tusangga, while they had not paid much attention to the Kirghiz attacks against the Torghuds up to this point, acknowledged that Mingilha

5. Levey, "Jungar Refugees and the Making of Empire," 267-70.

6. Noda Jin and Onuma Takahiro, A Collection of Documents from the Kazakh Sultans to the Qing Dynasty (Tokyo: The University of Tokyo, 2010), 86-125. 
had done the right thing, telling Ioitubes: "Now the Torghuds have submitted to the great emperor, they have become albatu just like you (te turgūt $i$ urse amba ejen de dahame dosifi, suweni adali albatu oho)."

Here we see the amban's equation of the Sayaq Kirghiz and the newly submitted Torghuds. At this point, I should note that the Sayaq Kirghiz lived outside Qing Altishahr (southern Xinjiang) and in fact were normally not under the jurisdiction of the amban, Qing officials stationed in key cities throughout Xinjiang. The Torghuds, in contrast, had become Qing subjects with their submission in July and were in the process of being settled in Qing Zungharia under the jurisdiction of the amban. Here, then, we have at least two definitions of albatu. On the one hand, all who submitted to the Qing emperor (ejen) were his albatu. On the other hand, some albatu, like the Torghuds, were more firmly incorporated into the Qing imperial order as Qing subjects.

\section{Ten Slave Narratives from October 1771 to September 1772}

From October 1771 to September 1772, there are at least ten recorded cases (Table 1) in which Torghuds escaped Kirghiz slavery to be reunited with their tribes and newly incorporated as Qing subjects. In six cases, the Torghud slaves fled to Qing Altishahr after hearing rumors of freedom there. In four cases, the Kirghiz masters delivered the Torghud slaves to the Qing amban in Altishahr after hearing that the Torghuds had become the Qianlong emperor's albatu. The Torghuds themselves provided these slave narratives to the Qing. As such, the narratives afford the historian rare glimpses into slavery in eighteenth-century Central Asia. Below, I will analyze the narratives in three sections: initial capture and slavery, rumors of freedom and escape, and incorporation as Qing subjects along with family reunification. ${ }^{8}$

\section{Initial Capture and Slavery}

According to those slave narratives that provide some detail about the circumstances of the initial capture, most of these Torghuds were captured by the Kirghiz in the areas around the Talas River, the Chu River, and the Lake Issyk Kul in today's northern Kyr-

7. Zhongguo diyi lishi dang'anguan and Zhongguo bianjiang shidi yanjiu zhongxin, eds., Qingdai Xinjiang Manwen dang'an huibian, (Guilin: Guangxi shifan daxue chubanshe, 2012) (QXMDH hereafter), 102: 131b-133b (palace memorial by Iletu and Tusangga; QL36.8.22=9/30/1771).

8. QXMDH, 102: 259a-262a (palace memorial by Iletu and Tusangga; QL36.9.16=10/23/1771), 102: 404b-406a (palace memorial by Fusembu and Suldei; QL36.10.3=11/9/1771), 103: 264a-b (palace memorial by Tusangga; QL36.11.6=12/11/1771), 104: 170b-172a (palace memorial by Fusembu and Suldei; QL36.12.24=1/28/1772), 105: 44b-46b (palace memorial by Fusembu and Suldei; QL37.1.26=2/29/1772), 105: 309b-312a (palace memorial by Antai and Tusangga; QL37.2.30=4/2/1772), 107: 156a-158a (palace memorial by Fusembu and Suldei; QL37.6.11 =7/11/1772), 108: 197a-198b (palace memorial by Fusembu and Suldei; QL37.8.27=9/23/1772). 
Table 1: Ten Slave Narratives, October 1771-September 1772

\begin{tabular}{|c|c|c|}
\hline Torghud Narrators & Path to Freedom & $\begin{array}{l}\text { Date of Contact with the } \\
\text { Qing amban }\end{array}$ \\
\hline $\begin{array}{l}\text { Arakba, 42-year-old man under zaisang } \\
\text { G'angdzaktu; Bekelik, 18-year-old man under } \\
\text { zaisang G'angdzaktu }\end{array}$ & $\begin{array}{l}\text { Handover by the Qushchu } \\
\text { Kirghiz at Uchturfan }\end{array}$ & October 22, 1771 \\
\hline $\begin{array}{l}\text { Eselbek, 19-year-old man under taiji Tsebeg- } \\
\text { Dorji; Derte, 18-year-old man under taiji } \\
\text { Ubashi }\end{array}$ & $\begin{array}{l}\text { Escape from the Basïz } \\
\text { Kirghiz to Kashgar }\end{array}$ & November 5, 1771 \\
\hline Holhona, 39-year-old man under zaisang Undun & $\begin{array}{l}\text { Escape from an Andijani to } \\
\text { Uchturfan }\end{array}$ & December 1, 1771 \\
\hline Serin, 17-year-old man under zaisang Gabeimcu & $\begin{array}{l}\text { Escape from the Kirghiz to } \\
\text { Kashgar }\end{array}$ & Most likely January 1772 \\
\hline Dorji, 35-year-old man under zaisang Kuišukun & $\begin{array}{l}\text { Escape from the Kirghiz to } \\
\text { Kashgar }\end{array}$ & February 5, 1772 \\
\hline Batur, 25-year-old man under zaisang Kuišukun & $\begin{array}{l}\text { Handover by the Chong- } \\
\text { Bagïsh Kirghiz at } \\
\text { Kashgar }\end{array}$ & February 7, 1772 \\
\hline Dorji, 18-year-old man under zaisang Dzalubaksi & $\begin{array}{l}\text { Handover by the Sayaq } \\
\text { Kirghiz at Uchturfan }\end{array}$ & March 27, 1772 \\
\hline Hasiha, 48-year-old man under zaisang Pisirel & $\begin{array}{l}\text { Handover by the Adigine } \\
\text { Kirghiz at Kashgar }\end{array}$ & Most likely July 1772 \\
\hline $\begin{array}{l}\text { Iši and Anci, son and mother under zaisang } \\
\text { Undunbabai }\end{array}$ & $\begin{array}{l}\text { Escape from the Cherik } \\
\text { Kirghiz to Kashgar }\end{array}$ & Most likely September 1772 \\
\hline Jamai, a man under zaisang Norbucereng & $\begin{array}{l}\text { Escape from the Cherik } \\
\text { Kirghiz to Kashgar }\end{array}$ & Most likely September 1772 \\
\hline
\end{tabular}

gyzstan. As we have seen, the Torghuds had been greatly weakened by this point due to Kazakh raids against them. The testimony of Eselbek, a Torghud man under the rule of taiji Tsebeg-Dorji (Ma. Ts'ebekdorji), confirms this point. Eselbek stated that he was captured by a Basïz Kirghiz named Madak in the Chu-Talas region, by which point the Torghuds had become exhausted and scattered after fending off Kazakh raids a few times. Derte, a subordinate of taiji Ubashi, was also seized in the Chu-Talas region by the Solto and other Kirghiz tribes. ${ }^{9}$ For the other Torghuds captured in northern Kyrgyzstan, we get more specific locales. Arakba and Bekelik, Torghud men under zaisang (Ma. jaisang) G'angdzaktu, were captured by the Bugu Kirghiz in Gürban Alimtu. ${ }^{10}$ Holhona, a 39-year-old man under zaisang Undun, was captured by the Kirghiz at Alimtu. ${ }^{11}$ Dorji, an 18-year-old man under zaisang Dzalubaksi, was also captured by the Sarï-Bagïsh Kirghiz in Alimtu. ${ }^{12}$

9. QXMDH, 102: 404b-406a (palace memorial by Fusembu and Suldei; QL36.10.3=11/9/1771). Taiji was the title of nobility used by the Mongols and Oirats. See Atwood, Encyclopedia of Mongolia and the Mongol Empire, 525-6.

10. QXMDH, 102: 259a-262a (palace memorial by Iletu and Tusangga; QL36.9.16=10/23/1771). Zaisang was the title of minor nobility or petty officials among the Oirats under Qing rule and the Kalmyks under Russian rule. See Atwood, Encyclopedia of Mongolia and the Mongol Empire, 30-2, 288-93.

11. QXMDH, 103: 264a-b (palace memorial by Tusangga; QL36.11.6=12/11/1771).

12. QXMDH, 105: 309b-312a (palace memorial by Antai and Tusangga; QL37.2.30=4/2/1772). 
A common theme that runs through slavery across time and space is the forced separation of the individuals from their family, kin, and community. It was this loss of status and identity that left the newly enslaved exposed in their new environments. ${ }^{13}$ For most of the captured Torghuds, the initial capture also marked the moment of isolation from their home society and most often their families. Dorji's capture by the Sarï-Bagïsh Kirghiz at Alimtu, for example, separated Dorji from his three older brothers and his father. ${ }^{14}$ The case of Anci and Iši, a mother and son who were captured by the Bugu Kirghiz, is the rare exception. Even for them, their initial capture separated them from each other. It was not until they were circulated among the Kirghiz as chattel that Anci and Iši were reunited as slaves to the Cherik Kirghiz. ${ }^{15}$

As can be seen from the case of Anci and Iši, it was common for Kirghiz captors to sell or give away the captured Torghuds to others. Derte, for example, was eventually given to a Basïz Kirghiz named Doliyat and forced to herd his horses and sheep. ${ }^{16}$ The Bugu Kirghiz who captured Arakba and Bekelik sold them to two Qushchu Kirghiz who were visiting their relatives. ${ }^{17}$ Dorji's slave narrative is unique in that it reveals the price of Dorji's sale. Here Dorji's master Sayaq biy Mingilha reported that he bought Dorji from the Sarï-Bagïsh Kirghiz for the price of one camel. ${ }^{18}$ Holhona's slave narrative also sets itself apart from the other narratives, as Holhona was eventually sold to an Andijani merchant named Setibhuli, who later took him on the trade routes across Central Asia. ${ }^{19}$

The experiences of Dorji and Holhona show that the Kirghiz slave raid of the Torghuds was connected to the larger phenomenon of captive exchange economy that previous scholarship has noted. Benjamin Levey, for example, has shown that Oirats were enslaved in large numbers all across Central Asia during and after the Qing conquest of Xinjiang. The Qing amban in Zungharia were acutely aware of this problem and even instituted a program of paying ransom money to the Oirats' Kazakh and Altishahri masters. ${ }^{20}$ L. J. Newby has also shown that bondage was a common phenomenon in eighteenth- and nineteenth-century Xinjiang. Moreover, she shows how Xinjiang was where Central Asian and Chinese contexts of bondage intersected. ${ }^{21}$

Whether the captured Torghuds were kept by their captors or not, the Torghud slaves shared common experiences during their bondage under the Kirghiz: forced labor and abuse from their Kirghiz masters. As slaves, the captured Torghuds often performed

13. Seymour Drescher, Abolition: A History of Slavery and Antislavery (Cambridge: Cambridge University Press, 2009$), 20$.

14. QXMDH, 105: 309b-312a (palace memorial by Antai and Tusangga; QL37.2.30=4/2/1772)

15. QXMDH, 108: 197a-198b (palace memorial by Fusembu and Suldei; QL37.8.27=9/23/1772).

16. QXMDH, 102: 404b-406a (palace memorial by Fusembu and Suldei; QL36.10.3=11/9/1771).

17. QXMDH, 102: 259a-262a (palace memorial by Iletu and Tusangga; QL36.9.16=10/23/1771).

18. QXMDH, 105: 309b-312a (palace memorial by Antai and Tusangga; QL37.2.30=4/2/1772).

19. QXMDH, 103: 264a-b (palace memorial by Tusangga; QL36.11.6=12/11/1771).

20. Levey, "Jungar Refugees and the Making of Empire on Qing China's Kazakh Frontier, 1759-1773," 77-86.

21. L. J. Newby, “Bondage on Qing China's Northwestern Frontier," Modern Asian Studies 47, no. 3 (2013): 968-94. 
two main tasks. The first, unsurprising given the nomadic way of life common between the Torghuds and the Kirghiz, was taking care of the Kirghiz herd. Eselbek and Derte, who escaped together from their Basiz Kirghiz masters, recollected being forced to herd their masters' livestock every day. Derte, for example, had to take care of his Basïz master Doliyat's horses and sheep. Serin, likewise, had to herd sheep and gather wood for his master Nidzar every day. ${ }^{22}$ As Serin's case hints, the second set of tasks awaiting the captured Torghuds was taking care of general household duties for their masters. In this role, the captured Torghuds frequently interacted with their Kirghiz masters, which unfortunately tended to include mistreatment and abuse. Arakba and Bekelik, for example, were abused for several months while working as house slaves for their Bugu captors before being sold off to other Kirghiz. ${ }^{23}$

\section{Rumors of Freedom and Escape}

For some of the enslaved Torghuds, the language barrier prevented them from hearing about the potential for attaining freedom. This problem was only resolved by encounters with Mongolian speakers. Eselbek, for example, could not really understand the speech of the Basïz Kirghiz. It was not until he met an Oirat female slave that he learned about his path to freedom. The woman told him that at several days' journey east lay the city of Kashgar, where the Qing amban were stationed. Eselbek kept this information in mind and relayed the information to Derte when the two met several days later. Together, they stole three horses and escaped the Basïz pasture during the night, eventually reaching the Qing karun guard post at Üstün Artush and then being escorted to Kashgar. ${ }^{24}$ Serin was in a similar situation. As he could not understand the Kirghiz language, he could not even figure out which Kirghiz tribe he was with. It was not until he met a Kirghiz named Tutubek who understood Mongolian that he heard about Kashgar, which lay east of the pasture. Serin soon made his escape with some provisions and walked for ten days to reach the Qing karun at Arghu (Ma. Arhū). ${ }^{25}$ Dorji, a subordinate of Torghud zaisang Kuišukun, was forced to herd the livestock of his captor. While doing so, he heard from a woman who spoke Mongolian that the city of Kashgar lay east of the pasture, and he made his escape soon afterward. ${ }^{26}$

In three slave narratives, the enslaved Torghuds were initially unaware that the Torghuds had been incorporated as Qing subjects. Iši and Anci, the mother and son enslaved by the Cherik Kirghiz, did not know about the possibility of freedom until

22. QXMDH, 102: 404b-406a (palace memorial by Fusembu and Suldei; QL36.10.3=11/9/1771), 104: 170b-172a (palace memorial by Fusembu and Suldei; QL36.12.24=1/28/1772).

23. QXMDH, 102: 259a-262a (palace memorial by Iletu and Tusangga; QL36.9.16=10/23/1771).

24. QXMDH, 102: 404b-406a (palace memorial by Fusembu and Suldei; QL36.10.3=11/9/1771).

25. QXMDH, 104: 170b-172a (palace memorial by Fusembu and Suldei; QL36.12.24=1/28/1772).

26. QXMDH, 105: 44b-46b (palace memorial by Fusembu and Suldei; QL37.1.26=2/29/1772). 
Muslim traders came to the Cherik pasture. From the traders, they learned that the Torghud escapees who arrived at Kashgar were being sent to Ili to be reunited with their tribes there. A Torghud man named Jamai, who was working as a slave for his Bugu Kirghiz captor Sarbasi, heard similar news from Muslim traders visiting the Bugu pasture. All three made their escape soon afterward and eventually reached Kashgar. In the third case, Holhona did not know about the possibility of freedom in Qing Altishahr until he accompanied his Andijani master Setibhuli on a trading trip to Uchturfan. Once he heard about the presence of the Qing amban in Uchturfan, he submitted to Qing soldiers at a relay station and was escorted to Uchturfan. ${ }^{27}$

In the four cases where the Kirghiz handed over captured Torghuds to a Qing amban, the transfer process began with the Kirghiz chieftains learning about the new status of the Torghuds as Qing subjects. These are the cases that highlight the boundaries of subjecthood that existed in Qing's Central Asian frontier. Qushchu biy Berke's visit to Uchturfan with Torghuds Arakba and Bekelik in October 1771 provides a great example. According to Berke, his subordinates had bought these Torghuds from the Bugu Kirghiz while visiting their relatives. Since he had heard that the Torghuds were now the Qianlong emperor's subjects (Ma. amba ejen $i$ aha albatu), Berke dared not keep these Torghuds in his tribe and brought them to the Uchturfan amban. Berke pastured at Qaqshal (Ma. Hakšal), about 300 li west of Uchturfan, and was under the jurisdiction of the Uchturfan amban. Given his frequent interactions with the Qing amban at Uchturfan and Kashgar, it is not surprising that Berke knew about the Torghuds' incorporation as Qing subjects. Material gain does not seem to have been a factor either. The Uchturfan amban initially rewarded Berke with the basic provisions of sheep and flour, and it was not until he was ordered by the Qianlong emperor that the amban granted Berke a bolt of silk as a reward for his action. ${ }^{28}$

Next, we see Chong-Bagïsh biy Awal bringing the Torghud man Batur to Kashgar in February 1772. Awal pastured at Toyun (Ma. toyung) and Qizil Oy Tamalak (Ma. hedzel oi tamalak) north of Kashgar. He was under the jurisdiction of the Kashgar amban and maintained a close relationship with them. Accordingly, Awal already knew that the Torghuds had submitted and were being settled in the areas around Ili when his subordinate Hailiyandar bought Batur from the Bugu Kirghiz and brought him to the ChongBagish pasture. Here again, Awal reported that he brought Batur to Kashgar because Awal did not dare to keep Batur in his pasture. Kashgar amban Fusembu and Suldei rewarded Awal with half a bolt of silk, telling him: "Torghuds and Khoshuds have all

27. QXMDH, 108: 197a-198b (palace memorial by Fusembu and Suldei; QL37.8.27=9/23/1772), 103: 264a-b (palace memorial by Tusangga; QL36.11.6=12/11/1771).

28. QXMDH, 102: 259a262a (palace memorial by Iletu and Tusangga; QL36.9.16=10/23/1771), 103: 381b-382b (palace memorial by Tusangga; QL36.11.20=12/25/1771), 105: 307b-308a (palace memorial by Antai and Tusangga; QL37.2.30=4/2/1772). 
become the great emperor's albatu. They, then, are the same as yourself (turgūt hoošot i jergi urse gemu ejen i albatu oho, inu uthai sini beye adali kai)!" ${ }^{29}$ This may superficially appear to be the same expression as the one uttered by the Uchturfan amban to Sayaq biy Mingilha, with the important difference that Mingilha was not under the jurisdiction of the Altishahr amban. The Torghuds, like the Chong-Bagïsh under Awal, were now firmly under Qing rule.

The two other cases involved the Kirghiz chieftains who pastured farther away from Altishahr and were not under the amban's jurisdiction. In March 1772, Sayaq biy Mingilha came back to Uchturfan with a Torghud man named Dorji. Mingilha reported that he had bought Dorji from the Sarï-Bagïsh Kirghiz for the price of one camel, as stated above, before hearing about the Torghud submission. Now that he knew, however, he would not dare to keep Dorji in his pasture. I should note that Mingilha may have had an ulterior motive. He had also brought his son Kūbatbek to introduce him to the Uchturfan amban, since Mingilha himself was already eighty-five years old and unlikely to make another trip to Uchturfan. Mingilha may have organized this whole trip to secure Kūbatbek's place as his chosen successor, and handing over Dorji may have been a secondary matter. In any case, Mingilha was rewarded with a bolt of silk. ${ }^{30}$

In summer 1772, two Adigine Kirghiz named Bakei and Sirgadz brought a Torghud man named Hasiha to the Kashgar amban. They had gone to the Bugu pasture to visit their relative Temur, who then gave them Hasiha. After returning to their pasture in the Osh area in today's southern Kyrgyzstan, however, they learned that the Torghuds had been settled in Ili and other places in Qing Xinjiang. They would not dare to keep Hasiha in their pasture, but brought him to Kashgar. The Adigine pastured even farther away from Altishahr than the Sayaq, but they were also considered to be the albatu of the Qianlong emperor. In that sense, Bakei and Sirgadz were fulfilling their duties as albatu. $^{31}$

Whether the narratives were told by the enslaved Torghuds or the Kirghiz masters, there are two common themes running through them. First, information spread quickly across Qing Xinjiang and the Kirghiz pastures. Despite the language barrier and the geographic barriers, the news of Torghud submission to the Qing was being carried by traveling caravans and Kirghiz nomads. Note that these stories all took place within two and fourteen months of the Torghud being settled and accepted as Qing subjects. Second, to all who heard the news, it was clear that the Torghuds had been transformed from nomads unconnected to the Qing empire to new subjects of the Qianlong emperor.

29. QXMDH, 105: 44b-46b (palace memorial by Fusembu and Suldei; QL37.1.26=2/29/1772). Some of the Volga Khoshuds accompanied the Torghuds from the Volga to Zungharia. On the Khoshuds, see Atwood, Encyclopedia of Mongolia and the Mongol Empire, 310.

30. QXMDH, 105: 309b-312a (palace memorial by Antai and Tusangga; QL37.2.30=4/2/1772),

31. QXMDH, 107: 156a-158a (palace memorial by Fusembu and Suldei; QL37.6.11=7/11/1772). 
To the captured Torghuds, this meant that the Qing amban could now grant them freedom. To the Kirghiz masters, it meant that they were keeping Qing subjects enslaved in their pastures-a potentially dangerous game.

\section{Incorporation as Qing Subjects}

Upon their arrival at Kashgar and Uchturfan, the formerly enslaved Torghuds were interviewed by the amban. The interviews started with a uniform series of questions aimed at getting the basic information on individual Torghuds: name, age, and affiliation. It was the narrative portion, which had the Torghuds explain how they had come to Altishahr, that constituted the backbone of the interview. This is also where most of my analysis in the previous section comes from: the circumstances of the initial capture, life of bondage, path to freedom, presence of family members, and so on.

As these escaped Torghuds were arriving at Altishahr, the Qing officials at Ili were finalizing the logistics of permanently settling the Torghuds as new Qing subjects. In the end, they decided to settle them into different pastures: Tseren's people in the Altai, far from the other Torghuds; Ubashi's followers at Jair; Tsebeg-Dorji's group at Hoboksar (Ma. hobok sari); and so on. ${ }^{32}$ In any case, the escaped Torghuds in Altishahr had to first arrive at Ili before they could be settled in their new pastures. As such, the Altishahr amban provided the escaped Torghuds with necessary provisions for the journey. Torghuds without proper clothing were provided with basic clothing, a short fur jacket (Ma. jibca) to protect against the cold, and boots. Considering the extreme cold weather of the region, the lack of clothing for some of these Torghuds highlights another hardship they had to suffer under Kirghiz slavery. Serin, for example, who had walked for ten days to reach a Qing karun in Kashgar in January 1772, received both a fur jacket and a pair of boots. We can only imagine how harsh Serin's journey must have been. ${ }^{33}$

The Collective Report Proposal of September 1772 and the Routinization of Information

On September 1, 1772, Uchturfan amban Antai and Kashgar amban Fusembu and Suldei presented a joint palace memorial to the Qianlong emperor. In this memorial, they reviewed how Torghuds escaping Kirghiz slavery had been handled in the previous year. Then, they recommended handling similar cases in the future according to precedent and then collectively reporting on them. The Qianlong emperor's approval transformed these cases from individual cases important in their own rights to routine bureaucratic

32. Levey, "Jungar Refugees and the Making of Empire on Qing China's Kazakh Frontier, 1759-1773," $256-66$. 33. QXMDH, 104: 170b-172a (palace memorial by Fusembu and Suldei; QL36.12.24=1/28/1772). 
Table 2: Three Collective Reports from Kashgar, October 1771-September 1772

\begin{tabular}{ll}
$\begin{array}{l}\text { Date of Report (Dates of } \\
\text { the Cases) }\end{array}$ & Data on the Freed Slaves \\
\hline $\begin{array}{l}\text { January 1773 (August } \\
\text { 1772-January 1773) }\end{array}$ & $\begin{array}{l}\text { Five Torghud men escaping from the Kirghiz } \\
\text { One Khoshud boy handed over by an Andijani } \\
\text { One Torghud man handed over by a Kirghiz }\end{array}$ \\
$\begin{array}{l}\text { February 1774 (January } \\
\text { 1773-February 1774) }\end{array}$ & $\begin{array}{l}\text { One Torghud man and one Khoshud woman escaping from the Kirghiz } \\
\text { One Torghud man handed over by an Andijani }\end{array}$ \\
February 1775 (February & $\begin{array}{l}\text { Five Torghud men escaping from the Kirghiz or taken from the } \\
\text { Kashgaris }\end{array}$ \\
\hline
\end{tabular}

procedures. ${ }^{34}$ The Qing documentation from this point on reflects this transformation, as individual narratives were largely replaced with quantitative data. ${ }^{35}$

The first three collective reports from the Kashgar amban illustrate this point well. In a January 1773 palace memorial, they reported on six Torghud men and a Khoshud boy who had escaped Kirghiz slavery or been turned over in the past five months. Five of the Torghud men had escaped from the Kirghiz, while one Torghud man and the Khoshud boy were handed over to the Kashgar amban by their Andijani and Kirghiz masters. While their names were recorded, none of the personal details that made individual slave narratives unique survive in this routine document. We just learn that they were all escorted to Ili after receiving clothing and provisions. ${ }^{36}$ The next memorial on such cases, written in February 1774, covered three from the previous year. Here again, gone is the detailed information on the initial capture, experience of slavery, and the path to freedom. All we learn is that a Torghud man and a Khoshud man who escaped from the Kirghiz, as well as a Torghud man who was handed over by his Andijani master, received clothing and provisions for their journey to $\mathrm{Ili}^{3}{ }^{37}$ The third memorial, from February 1775, also covered the previous year in its entirety: five Torghud men escaping from the Kirghiz or taken from Kashgari merchants who bought them from the Kirghiz were escorted to Ili and Karashahr. The expression "searched and taken from (Ma. baicame tucibuhe)" hints that this may have been a result of a check at a karun guard post, but this document is so succinct that it is impossible to get much information on the process. ${ }^{38}$

In short, the routinization proposal of September 1772 took away an important body of archival sources that the historian can use as a window to look at lived experiences

34. QXMDH, 108: 246a-247a (palace memorial by Antai, Fusembu, Suldei; QL37.9.1=9/27/1772).

35. QXMDH, 110: 369b-371b (palace memorial by Fusembu and Suldei; QL37.12.24=1/16/1773), 117: 376a-377a (palace memorial by Fusembu and Suldei; QL38.12.21 =2/1/1774), 122: 218a-219a (palace memorial by Fusembu and Šuboo; QL40.1.8=2/7/1775).

36. QXMDH, 110: 369b-371b (palace memorial by Fusembu and Suldei; QL37.12.24=1/16/1773).

37. QXMDH, 117: 376a-377a (palace memorial by Fusembu and Suldei; QL38.12.21 =2/1/1774).

38. QXMDH, 122: 218a-219a (palace memorial by Fusembu and Šuboo; QL40.1.8=2/7/1775). 
of the Torghuds who were enslaved by the Kirghiz and eventually found freedom as Qing subjects. Still, we can make a couple of observations from the above data. First, all thirteen Torghuds who found freedom in Kashgar between September 1772 and January 1775 were men, which corresponds to the findings from the previous section, where all were men except for one woman, the mother of one of the men. Second, these Torghuds were owned by Kirghiz, Andijanis, and Kashgaris. This is a further piece of evidence that the Torghuds were moved across Qing's Central Asian frontier as a part of wider slave market. This corresponds to the findings by B. D. Hopkins and L. J. Newby, who have shown that trade in slaves were widespread in Central Asia of the nineteenth century. ${ }^{39}$

To conclude this section, let me turn to a February 1781 palace memorial by the Kashgar amban that diverges from this norm of routine information. This may well have been another collective report save for the fact that only one Torghud man escaped to Kashgar from the previous year. This was Haban, a subordinate of Torghud zaisang Tsebeg-Dorji. From Haban's testimony, we learn that his grandfather zaisang Gertaimairgiyan died on the way from the Volga to Ili in the Torghud return to their old pastures. Haban himself was captured by a Qushchu Kirghiz named Buthaci in Alimtu. We may recall that a few of the escaped Torghuds analyzed in the previous section were also captured in the same locale, which was in northern Kyrgyzstan. Unlike those Torghuds, however, Haban endured ten years as a house slave of Buthaci, which was accompanied by constant abuse and mistreatment. After hearing from traders about the presence of the Qing amban in Kashgar, he escaped the Qushchu pasture and arrived at the Arghu karun on August 14, 1780. The Kashgar amban, according to precedent, had him escorted to Ili so that he could join his father and the rest of his family at TsebegDorji's pasture at Jair. ${ }^{40}$

\section{Conclusion}

As demonstrated by Hoban's case, there were Torghuds who endured slavery for an extended period of time. The last collective memorial I have found on the escaped Torghuds comes from May 1785. Written by Ili military governor Iletu, it tersely states that six Torghud men who escaped from the Kazakhs and the Kirghiz between February and May were settled with their leaders. This would mean that these Torghuds had endured slavery for fourteen years before finding their freedom. Undoubtedly, there were many who never escaped their masters and died as slaves in foreign lands away from their family members. ${ }^{41}$

39. Newby, "Bondage on Qing China's Northwestern Frontier”; B. D. Hopkins, “Race, Sex and Slavery: 'Forced Labour' in Central Asia and Afghanistan in the Early 19 ${ }^{\text {th }}$ Century," Modern Asian Studies 42, no. 4 (2008): 629-71. 40. QXMDH, 145: 311b-312b (palace memorial by Mahingga and Dunfu; QL46.1.25=2/17/1781).

41. QXMDH, 167: 415a-b (palace memorial by Iletu; QL50.4.7=5/15/1785). 
Why did some Kirghiz not turn in their slaves, when others did? Part of the answer must lie with the fact that Qing officials in Xinjiang never adopted an active policy to seek out the Torghuds enslaved among the Kirghiz. They were happy to greet the escaped Torghuds, receive the Torghuds handed over by their masters, or possibly even search the caravans coming into Altishahr at the karun guard posts. On the other hand, they neither searched the Kirghiz pastures nor actively paid out ransom money for the enslaved Torghuds. ${ }^{42}$ This passive policy by the Qing officials crystalized the boundaries of Qing subjecthood for the enslaved Torghuds. For the Torghuds to become the albatu of the Qianlong emperor and thus become free, they had to get to the karun guard posts of Altishahr, if not the seats of the amban at Uchturfan and Kashgar themselves. Beyond the karun, they remained properties of their Kirghiz masters, even though the Kirghiz were also the albatu of the Qianlong emperor. The Torghud experiences of bondage and freedom, then, show the tangled web of subjecthood and albatu-hood that existed in and beyond Qing Xinjiang.

Unfortunately for the Torghuds who did escape slavery, the prospects awaiting them as new Qing subjects were not great. Michael Khodarkovsky, for one, has stated that the Torghuds "had escaped Russian tentacles only to be ensnared in Chinese ones." 43 This conclusion is supported by Benjamin Levey's meticulous analysis of the Qing policies toward the Torghuds. According to Levey, the Torghuds, who were already in great poverty due to the Kazakh raids and a smallpox epidemic, further suffered from the failed Qing policy to turn these nomads into farmers. With this agrarian transformation, the Qianlong emperor believed, the Torghuds would lose their "martial prowess and manly vigor," contributing to stability among them. In fact, this disastrous policy backfired and resulted in extreme poverty in Ubashi's pastures. The Qing officials, worried that the Torghuds might return to Russia or rebel against Qing, had to carry out a series of programs to relieve Torghud poverty. ${ }^{44}$ These were, however, short-term measures. Split up into ten banners across hundreds of kilometers, with restricted freedom of movement and action, the Torghuds suffered from poverty throughout the rest of the Qing period. ${ }^{45}$

Concluding his analysis of the Return of the Torghuds, Perdue stated: "In hindsight, which group made the best choice: those who left the Volga, or those who stayed behind? . . . We could debate the wisdom of their choice, but it is clear that when

42. The anonymous reviewer raised the interesting question of whether the Qing state had an equally passive policy toward the Torghuds enslaved by the Kazakhs. While Benjamin Levey does not address this point in his dissertation, he shows that the Qing protocol on the Oirats enslaved by the Kazakhs was also passive. The Qing amban accepted the Oirats who escaped Kazakh slavery and even paid ransom money to the Kazakhs voluntarily selling their Oirat slaves to Qing officials. They did not, however, actively seek out to free the Oirats from Kazakh slavery beyond that. See Levey, "Jungar Refugees and the Making of Empire on Qing China's Kazakh Frontier, 1759-1773," 77-82.

43. Khodarkovsky, Where Two Worlds Met, 235.

44. Levey, “Jungar Refugees and the Making of Empire on Qing China's Kazakh Frontier, 1759-1773,” $256-302$.

45. Perdue, China Marches West, 297-8. 
these last free nomads came under domination from the great agrarian empires that surrounded them, the steppe ended, and a great chapter in world history closed." 46 Perdue's comment rightly highlights the division of Eurasia between the Qing and Russia and the subsequent fall of nomadism. Our analysis of the Torghud slave narratives makes it clear, however, there were worse options for the Torghuds than domination by the great agrarian empires. For some-those enslaved by the Kirghiz, for examplebecoming the Qianlong emperor's albatu meant freedom.

\section{Bibliography}

Atwood, Christopher P. Encyclopedia of Mongolia and the Mongol Empire. New York: Facts On File, 2004.

Drescher, Seymour. Abolition: A History of Slavery and Antislavery. Cambridge: Cambridge University Press, 2009.

Hopkins, B. D. "Race, Sex and Slavery: 'Forced Labour' in Central Asia and Afghanistan in the Early 19th Century." Modern Asian Studies 42, no. 4 (2008): 629-71.

Khodarkovsky, Michael. Where Two Worlds Met: The Russian State and the Kalmyk Nomads, 16001771. Ithaca: Cornell University Press, 1992.

Levey, Benjamin Samuel. "Jungar Refugees and the Making of Empire on Qing China's Kazakh Frontier, 1759-1773." Ph.D. dissertation, Harvard University, 2013.

Newby, L. J. "Bondage on Qing China's Northwestern Frontier.” Modern Asian Studies 47, no. 3 (2013): 968-94.

Noda Jin and Onuma Takahiro. A Collection of Documents from the Kazakh Sultans to the Qing Dynasty. Tokyo: The University of Tokyo, 2010.

Perdue, Peter C. China Marches West: The Qing Conquest of Central Eurasia. Cambridge, MA: Belknap Press of Harvard University Press, 2005.

Zhongguo diyi lishi dang'anguan and Zhongguo bianjiang shidi yanjiu zhongxin, eds. Qingdai Xinjiang Manwen dang'an huibian. 283 vols. Guilin: Guangxi shifan daxue chubanshe, 2012.

46. Perdue, China Marches West, 298-9. 